How to Cite

Gupta, D. (2018). Item-wise ANOVA analysis of human resource development climate in Indian information technology

organizations. International Journal of Life Sciences \& Earth Sciences, 1(1), 29-38. https://doi.org/10.31295/ijle.v1n1.11

\title{
Item-wise ANOVA Analysis of Human Resource Development Climate in Indian Information Technology Organizations
}

\author{
Deepakshi Gupta \\ Sikh National College, Banga, Punjab, India \\ Email:drdeepakshi.cgc@gmail.com
}

\begin{abstract}
Human resource development climate is an integral part of organizational climate. The present paper examines ANOVA analysis of human resource development climate of different information technology organizations in India. The study is based on survey of in 13 selected information technology organizations such as Tata Consultancy Services, Wipro Technologies, Infosys Technologies Ltd., Hindustan Computer Ltd. (HCL), Dell International, Birlasoft, Pyramid Consulting Inc., Quark Inc., Semi-Conductor Laboratory (SCL Ltd.), AlcatelLucent Technologies, Attra, Kanbay International and Omnia Technologies from Delhi, Bangalore, Pune, Chandigarh and Mohali respectively. The results from ANOVA analysis proves that human resource development climate in information technology sector varies from organization to organization.

Keywords---ANOVA analysis, human resource development climate, information technology organizations.
\end{abstract}

\section{Introduction}

Human resources are the most valuable and unique asset of an organization. Nowadays, the world has become a global village, so managing and developing different employees belonging to different cultures under one organization is a very dynamic and challenging task. The nature of the human resource is not similar in mental abilities, traditions, sentiments, and behavior. They are widely different from each other as an individual person and as a group of persons. It is very difficult to attract, develop, retain and satisfy all employees simultaneously for an organization to get a desirable outcome. It is, therefore, necessary for all human resources managers to understand and give due importance to the different human resource policies and activities in the organization (Mamoria \& Gankar, 2002; ICFAI 2004). Peter Drucker, who is credited with the first coining of the term 'Knowledge Workers' or 'Knowledge HR', observed in his book, Post Capital Society (1993), that we are entering in a knowledge society. Where the basic economic resource is no longer capital, natural resource or labor but is and will be knowledge workers who play a central role. He suggested that various classes of knowledge workers, of which high knowledge workers include professionals, such as doctors, teachers, and consultants, who deal mainly in the realm of the mind. While on the other hand, another class of knowledge workers is - the knowledge technicians who work with their hands and brains in the industries of IT, medical and other areas. In highly skilled intensive and knowledge-intensive industries like information technology industry, human resource plays a vital role. This industry needs highly skilled, talented and well-learned human resource.

\section{Objectives of Present Study}

The objectives of the present study," Item-Wise ANOVA Analysis of Human Resource Development Climate in Indian Information Technology Organisations" is as follows:

a) To observe and analyze the human resource development climate prevailing in the information technology industry.

b) To analyze and compare the human resource development climate prevailing in the selected information technology organizations.

ISSN 2632-9425

Received Jan 10, 2018 / Accepted Jun 20, 2018 / Published Jul 05, 2018 
c) To examine the human resource development climate in different Indian information organizations is similar or dissimilar.

\section{Review of Literature}

A survey of human resource development practices was conducted by Rao (1984), covering 53 different organizations in India. This survey indicates, by and large, a positive trend of using open appraisal system, improving the training function, making up organizational development activities and using employees counseling by an increasingly large number of companies. All in all, human resource development seems to be becoming a significant aspect of work and life in many organizations. Rao \& Abraham (1991), studied the human resource development climate in the surveyed organizations and found it to be at an average level in India. Aileni (1995), examined the relationship between organizational climate and job satisfaction of the lower level managers in a public sector undertaking. The study reveals that the satisfied group gave top ranks to an interpersonal relationship, risktaking, and management of rewards. On the other side, the dissatisfied group gave top priority to supervision, communication, and decision-making. Jain \& Singhal (1997), study took into account three human resource development mechanisms including management policy, potential appraisal and organizational development to study variances of human resource development climate on account of these mechanisms. The effect of personal factors on human resource development climate was found to be low but positive. Pillai (2000), makes an attempt to study the influence of the human resource development climate existing in banks on the learning orientation of the employees. The findings of the study show that about 57 percent of respondents perceive the learning, and development climate existing in banks as moderate. Pattanayak (2000), conducted a study on, the effect of shift-work and hierarchical position on satisfaction, commitment, stress and human resource development climate in a steel plant. The study calls for greater emphasis to be laid on human resource development interventions for improving organizational synergy. Tripathi \& Nachiketa Tripathi (2002), studied the relationship between organizational climate and organizational success; which includes effectiveness, job satisfaction, organizational commitment and intention to quit. The results show that the climate is highly correlated with all components of effectiveness. Ganesan et al., (2002), studied the 'Determinants of Employee Relations Climate in Public Sector Undertakings.' The study revealed that by improving factors like working conditions, level of supervision, communication and worker's participation etc. favorable climate can be achieved. Purang (2006), in a comparative study of Public, Private and Multinational organizations shows that the human resource development climate scores of the two private organizations and the MNC are significantly higher than the two PSUs. Majee (2006), study of Chittaranjan Locomotive Workshop finds a moderate level of HRD Climate with a lot of scope for improvement because HRD climate is the lifeblood of the organization. Mufeed (2006), highlights the need for a focus on key elements of human resource development in hospitals. Lim et al., (2006), study reveals that trainees' characteristics, instructional factors, and organizational climate are closely correlated with both the trainees perceived learning and learning transfer collectively. Srimannarayana (2007), attempted to assess the extent of human resource development climate in Dubai organizations, such as shipping, banking, tourism, trading, and food businesses. The results reveal the moderate level of general HRD climate in the organizations. Saraswathi (2010), study revealed that the three variables: General Climate, HRD Mechanisms and OCTAPACE culture (Openness, Confrontation, Trust, Autonomy, Pro-activity, Authenticity, Collaboration, and Experimentation) are better in software organizations compared to manufacturing organizations. (Kashi Singh \& Abhijit Bhattacharya 2008), conducted a study on, 'HighPerformance Organisations: Relationship with Human Resource Policies and Practices,' to examine the relationship between organizational performance and human resource policies and practices. It is hypothesized that human resource policies and practices will have a positive relationship with organizational performance. A list of 300 companies is prepared. The data used in this study is collected from 49 organizations consisting of 18 public sectors and 31 private sectors. Pearson correlation and step-wise regression analysis are used to analyze the data. For measuring organizational performance and human resource policy, five-point Likert-scale scores ranging from 1 to 5 is used. Saraswathi (2010), study revealed that the three variables: General Climate, HRD Mechanisms and OCTAPACE culture (Openness, Confrontation, Trust, Autonomy, Pro-activity, Authenticity, Collaboration, and Experimentation) are better in software organizations compared to manufacturing organizations. 


\section{Research Method}

In the present paper, organisation-wise ANOVA analysis of human resource development climate of information technology sector has been studied. The present research is carried out in 13 selected different information technology organisations, such as Tata Consultancy Services, Wipro Technologies, Infosys Technologies Ltd., Hindustan Computer Ltd. (HCL), Dell International, Birlasoft, Pyramid Consulting Inc., Quark Inc., Semi-Conductor Laboratory (SCL Ltd.), Alcatel-Lucent Technologies, Attra, Kanbay International and Omnia Technologies from Delhi, Bangalore, Pune, Chandigarh and Mohali respectively.

Human resource development climate survey includes the ten different dimensions of the study. These ten different dimensions are - rigorous selection process, value-based induction, comprehensive training, team-based job design, working conditions/environment, employee-friendly work environment, development-oriented performance appraisal, compensation, career development and value-added incentives. These dimensions include - 54 items in the questionnaire of human resource development climate survey. In this study five-point, Likert-scale has been used to evaluate the prevailing human resource development climate dimensions in information technology organizations.

\section{Results and Analysis}

\section{Sample-Size of Selected Information Technology Organisations}

The table 1 indicates that the sample size is different for different organizations. It ranged from 25 to 50 . Out of total 13 information technology organizations, eight organizations are software, four are BPOs and one is hardware.

\section{Item-Wise ANOVA Analysis of Different Information Technology Organisations}

One-way ANOVA analysis has been used to analyze the item-wise mean differences among the means of different 13 information technology organizations. Human resource development climate survey includes the ten different dimensions of the study. These ten dimensions include - 54 items in the questionnaire of human resource development climate survey. Item-wise ANOVA analysis of mean scores of various items in the human resource development climate survey shows that whether the item-wise mean scores among 13 organizations are significantly different from each other or not. If the calculated value of F statistic of an item is higher than the tabulated value at $1 \%$ or $5 \%$ level of significance, we can conclude that there are significant mean differences among 13 information technology organizations. Results of ANOVA analysis in table 2 show that all the item-mean scores of these organizations are significantly different from each other as the calculated values of $\mathrm{F}$ ratio are higher than tabulated values of $\mathrm{F}$ ratio. Thus, the null hypothesis of equal means of these organizations is rejected and we can conclude that human resource development climate varies from organization to organization.

\section{Conclusion}

Provide a statement that what is expected, as stated in the "Introduction" chapter can ultimately result in "Results and Discussion" chapter, so there is compatibility. Moreover, it can also be added the prospect of the development of research results and application prospects of further studies into the next (based on result and discussion).

Acknowledgments

The author would like to thank the editor for their valuable time and advice. 


\section{References}

Adetunji, A. T., Adetunji, A. V., Adeleke, E. O., \& Madubuike, S. C. (2017). Deregulation: The Effect of Market-led Approach to Nigerian Universities Management. International Journal of Social Sciences and Humanities (IJSSH), 1(1), 1-8.

Amerta, I. M. S. (2017). The Role of Tourism Stakeholders at Jasri Tourism Village Development, Karangasem Regency. International Journal of Social Sciences and Humanities (IJSSH), 1(2), 20-28.

Arnawa, I. K., Sukerta, I. M., Martiningsih, N. G. A. E., \& Astuti, P. S. (2017). Minapolitan Area Development Strategy: An Effort to Increase Fisherman Income, Gianyar Regency, Bali Indonesia. International Journal of Life Sciences (IJLS), 1(2), 39-47.

Aswathappa, K. (2013). Human resource management: Text and cases. Tata McGraw-Hill Education.

Brata, I. B., \& Pemayun, A. G. P. (2018). Human Resource Competency Tourism Bali together with ASEAN Economic Community. International Research Journal of Management, IT and Social Sciences (IRJMIS), 5(2), 186-194.

Drucker, P. F. (1988). The coming of the new organization.

Ganesan, D. P., Rajkumar, V. S., \& Saravanan, V. (2002). Determinants of Employee Relations Climate in Public Sector Undertakings. Management and Labour Studies, 27(4), 275-284.

Gupta, D., \& Malhotra, N. (2012). Human Resource Development Climate in Information Technology organizations. Gian Jyoti E-Journal, 2(3), 35-52.

Jain, V. K., \& Singhal, K. C. (1997). Some Correlates of HRD Climate: A Case Study of BHEL. Studies in Human Resource Development: HRD Practices: Assimilation and Implications, 213-219.

Lim, D. H., \& Morris, M. L. (2006). Influence of trainee characteristics, instructional satisfaction, and organizational climate on perceived learning and training transfer. Human Resource Development Quarterly, 17(1), 85-115.

Majee, K. K. (2006). Human Resources Climate Survey of Chittaranjan Locomotive Workshop (CLW). Management and Labour Studies, 31(1), 70-78.

Mani, d. P., \& kattigenahalli, y. Employees'perception towards human resource practices in airports authority of india at chennai. Chief patron chief patron.

Mora, M. M., Espinosa, M. R., \& Delgado, M. R. (2018). Approach of Processes for the Distribution of Economic Resources in Public University of Ecuador. International Research Journal of Management, IT and Social Sciences (IRJMIS), 5(1), 25-35.

Mufeed, S. A. (2006). The need for a focus on key elements of HRD climate in hospitals-an empirical study. Management and Labour Studies, 31(1), 57-69.

Pattanayak, B. (2000). Effects of Shiftwork and Hierarchical Position on Satisfaction, Commitment, Stress and HRD Climate: A Study on an Integrated Steel Plant. Management and Labour Studies, 25(2), 126-135.

Paul, A. K., \& Anantharaman, R. N. (2002). Impact of human resource management practices on competence of software professionals in India: An analytical study. Management and Change, 6, 94-111.

Pillai, P. R. (2008). Influence of HRD climate on the learning orientation of bank employees. Indian Journal of Industrial Relations, 406-418.

Purang, P. (2006). HRD Climate: A Comparative Analysis of Public, Private and Multinational Organisations. Indian Journal of Industrial Relations, 407-419.

Rao, T. V. (1986). Recent experiences in human resources development.

Saraswathi, S. (2010). Human resources development climate: An empirical study. International Journal of Innovation, Management and Technology, 1(2), 174.

Sharma, M., \& Ghosh, A. (2006). Perception, of organisational climate and job satisfaction in nursing staff personnel-Influence of personality and self-efficacy. Indian Journal of Social Work, 67(3), 263-274.

Singh, S., Singh, K. N., \& Bhattacharya, A. (2008). High Performance Organisations: Relationship with Human Resource Policies and Practices. Indian Journal of Industrial Relations, 507-527.

Srimannarayana, M. (2007). Human resource development climate in Dubai organisations. Indian Journal of Industrial Relations, 1-12.

Sukalyani, S., \& Pattanayak, B. (2004). Organisational Climate: An Exploratory Study on Nalco. Management and Labour Studies, 29(2), 109-119.

Tiwari, P., \& Saxena, K. (2012). Human resource management practices: A comprehensive review. Pakistan business review, 9(2), 669-705.

Tripathi, S., \& Tripathi, N. (2002). The effect of organisational climate on organisational success. Indian Journal of Industrial Relations, 161-176. 
Table 1

Sample Size of Selected Information Technology Organisations

\begin{tabular}{|c|c|c|c|}
\hline S. No. & Name of Organisations & Nature of Organisations & Sample-Size \\
\hline 1 & Tata Consultancy Services & Software & 30 \\
\hline 2 & Wipro Technologies & Software & 30 \\
\hline 3 & Infosys Technologies Ltd. & Software & 30 \\
\hline 4 & Hindustan Computer Ltd.(HCL) & $\mathrm{BPO}$ & 30 \\
\hline 5 & Dell International & $\mathrm{BPO}$ & 50 \\
\hline 6 & Birlasoft & Software & 25 \\
\hline 7 & Pyramid Consulting Inc. & $\mathrm{BPO}$ & 50 \\
\hline 8 & Semi-Conductor Laboratory (SCL) & Hardware & 30 \\
\hline 9 & Alcatel-Lucent Technologies & Software & 50 \\
\hline 10 & Attra & Software & 35 \\
\hline 11 & Kanbay International Inc. & Software & 40 \\
\hline 12 & Omnia Technologies & BPO & 50 \\
\hline 13 & Quark & Software & 50 \\
\hline
\end{tabular}

Source: Primary Survey

Table 2

Item-Wise ANOVA Analysis of Different Information Technology Organisations

\begin{tabular}{|c|c|c|c|c|c|}
\hline Particulars & ANOVA & Sum of Squares & $\mathrm{df}$ & Mean Squares & F \\
\hline \multicolumn{6}{|l|}{ (A) Rigorous Selection Process } \\
\hline \multicolumn{6}{|l|}{ 1. Select the candidates, our company conducts } \\
\hline \multirow[t]{3}{*}{ (a) Written Test } & Between groups & 27.2775 & 12 & 2.27 & ${ }^{*} 5.0113$ \\
\hline & Within groups & 220.9048 & 487 & 0.45 & \\
\hline & Total & 248.1823 & 499 & & \\
\hline \multirow[t]{3}{*}{ (b) Test On Programming Skills } & Between groups & 43.9785 & 12 & 3.66 & *8.0504 \\
\hline & Within groups & 221.7013 & 487 & 0.46 & \\
\hline & Total & 265.6798 & 499 & & \\
\hline \multirow[t]{3}{*}{ (c) Technical Interview } & Between groups & 32.4220 & 12 & 2.70 & ${ }^{*} 8.5253$ \\
\hline & Within groups & 154.3390 & 487 & 0.32 & \\
\hline & Total & 186.7610 & 499 & & \\
\hline \multirow[t]{3}{*}{ (d) General Interview } & Between groups & 47.3615 & 12 & 3.95 & ${ }^{*} 12.3562$ \\
\hline & Within groups & 155.5562 & 487 & 0.32 & \\
\hline & Total & 202.9177 & 499 & & \\
\hline \multirow{3}{*}{$\begin{array}{l}\text { 2. Our company looks at candidate's ability to work in a } \\
\text { team. }\end{array}$} & Between groups & 36.3835 & 12 & 3.03 & ${ }^{*} 7.0039$ \\
\hline & Within groups & 210.8198 & 487 & 0.43 & \\
\hline & Total & 247.2033 & 499 & & \\
\hline (B) Value-Based Induction & & & & & \\
\hline
\end{tabular}




\begin{tabular}{|c|c|c|c|c|c|}
\hline Particulars & ANOVA & Sum of Squares & $\mathrm{df}$ & Mean Squares & $F$ \\
\hline \multirow{3}{*}{$\begin{array}{l}\text { 1. Our Company organizes a formal induction programme } \\
\text { for new comers very effectively }\end{array}$} & Between groups & 65.7905 & 12 & 5.48 & ${ }^{*} 15.7927$ \\
\hline & Within groups & 169.0657 & 487 & 0.35 & \\
\hline & Total & 234.8562 & 499 & & \\
\hline \multicolumn{6}{|l|}{$\begin{array}{l}\text { 2. Induction training provides an excellent opportunity for } \\
\text { new comers to learn comprehensively about }\end{array}$} \\
\hline \multirow[t]{3}{*}{ (a) The organisation in general } & Between groups & 46.0720 & 12 & 3.84 & *9.2067 \\
\hline & Within groups & 203.0874 & 487 & 0.42 & \\
\hline & Total & 249.1594 & 499 & & \\
\hline \multirow[t]{3}{*}{ (b) Its mission and goals } & Between groups & 52.6185 & 12 & 4.38 & ${ }^{*} 10.6288$ \\
\hline & Within groups & 200.9095 & 487 & 0.41 & \\
\hline & Total & 253.5280 & 499 & & \\
\hline \multirow[t]{3}{*}{ (c) Its norms and values } & Between groups & 51.3160 & 12 & 4.28 & *11.7268 \\
\hline & Within groups & 177.5912 & 487 & 0.36 & \\
\hline & Total & 228.9072 & 499 & & \\
\hline \multirow[t]{3}{*}{ (d) Its customs } & Between groups & 54.8030 & 12 & 4.57 & ${ }^{*} 10.6395$ \\
\hline & Within groups & 209.0407 & 487 & 0.43 & \\
\hline & Total & 263.8437 & 499 & & \\
\hline \multirow{3}{*}{$\begin{array}{l}\text { 3. Induction training is used as an opportunity in our } \\
\text { company to create bonds between the company and the } \\
\text { new employees. }\end{array}$} & Between groups & 45.7780 & 12 & 3.81 & *8.9106 \\
\hline & Within groups & 208.4962 & 487 & 0.43 & \\
\hline & Total & 254.2742 & 499 & & \\
\hline \multirow{3}{*}{$\begin{array}{l}\text { 4. The new recruits find induction training very useful in } \\
\text { this organisation. }\end{array}$} & Between groups & 40.5905 & 12 & 3.38 & *7.0570 \\
\hline & Within groups & 233.4264 & 487 & 0.48 & \\
\hline & Total & 274.0169 & 499 & & \\
\hline \multicolumn{6}{|l|}{ (C) Comprehensive Training } \\
\hline \multirow{3}{*}{$\begin{array}{l}\text { 1. The training needs of each individual are identified } \\
\text { in order to develop critical skills needed for the } \\
\text { assigned work. }\end{array}$} & Between groups & 49.3988 & 12 & 4.12 & *8.2929 \\
\hline & Within groups & 241.7464 & 487 & 0.50 & \\
\hline & Total & 291.1452 & 499 & & \\
\hline \multirow{3}{*}{$\begin{array}{l}\text { 2. When employees are sponsored for training, they take it } \\
\text { seriously }\end{array}$} & Between groups & 70.8125 & 12 & 5.90 & *9.7018 \\
\hline & Within groups & 296.2131 & 487 & 0.61 & \\
\hline & Total & 367.0256 & 499 & & \\
\hline \multirow{3}{*}{$\begin{array}{l}\text { 3. The technical skills of the employees are constantly } \\
\text { upgraded through a variety of training programmes, } \\
\text { workshops and seminar }\end{array}$} & Between groups & 66.9480 & 12 & 5.58 & ${ }^{*} 11.9603$ \\
\hline & Within groups & 227.1664 & 487 & 0.47 & \\
\hline & Total & 294.1144 & 499 & & \\
\hline \multicolumn{6}{|l|}{ (D) Team-Based Job Design } \\
\hline \multirow{3}{*}{$\begin{array}{l}\text { 1. Self-managed work teams and semi-autonomous work } \\
\text { groups are the building blocks of the work system }\end{array}$} & Between groups & 51.1850 & 12 & 4.27 & ${ }^{*} 7.9903$ \\
\hline & Within groups & 259.9724 & 487 & 0.53 & \\
\hline & Total & 311.1574 & 499 & & \\
\hline
\end{tabular}




\begin{tabular}{|c|c|c|c|c|c|}
\hline Particulars & ANOVA & Sum of Squares & df & Mean Squares & F \\
\hline \multirow{3}{*}{$\begin{array}{l}\text { 2. The actual job duties are shaped more by the employees } \\
\text { than by a specific job description }\end{array}$} & Between groups & 32.1330 & 12 & 2.68 & *5.1195 \\
\hline & Within groups & 254.7257 & 487 & 0.52 & \\
\hline & Total & 286.8587 & 499 & & \\
\hline \multirow{3}{*}{$\begin{array}{l}\text { 3. Employees are given the details of the consumers and } \\
\text { their requirements }\end{array}$} & Between groups & 47.2480 & 12 & 3.94 & *9.5884 \\
\hline & Within groups & 199.9800 & 487 & 0.41 & \\
\hline & Total & 247.2280 & 499 & & \\
\hline \multirow{3}{*}{$\begin{array}{l}\text { 4. Individuals and groups are involved in making decisions } \\
\text { that affect their work }\end{array}$} & Between groups & 47.6630 & 12 & 3.97 & *9.3726 \\
\hline & Within groups & 206.3817 & 487 & 0.42 & \\
\hline & Total & 254.0447 & 499 & & \\
\hline \multicolumn{6}{|l|}{ (E) Working Conditions/ Environment } \\
\hline \multirow{3}{*}{$\begin{array}{l}\text { 1. The quality of physical conditions provided in the work- } \\
\text { place is good. }\end{array}$} & Between groups & 16.0200 & 12 & 1.34 & ${ }^{*} 2.9909$ \\
\hline & Within groups & 217.3712 & 487 & 0.45 & \\
\hline & Total & 233.3912 & 499 & & \\
\hline \multirow{3}{*}{$\begin{array}{l}\text { 2. Our company provider excellent infrastructure and } \\
\text { support services for high performance. }\end{array}$} & Between groups & 54.9965 & 12 & 4.58 & *8.2172 \\
\hline & Within groups & 271.6181 & 487 & 0.56 & \\
\hline & Total & 326.6146 & 499 & & \\
\hline \multirow{3}{*}{$\begin{array}{l}\text { 3. Sources of frequent interruption or distraction that } \\
\text { degrade the effectiveness of work environment are } \\
\text { identified and minimized }\end{array}$} & Between groups & 46.9715 & 12 & 3.91 & *9.0086 \\
\hline & Within groups & 211.6048 & 487 & 0.43 & \\
\hline & Total & 258.5763 & 499 & & \\
\hline \multirow{3}{*}{$\begin{array}{l}\text { 4. Periodic improvements are made to the work } \\
\text { environment that increases effectiveness in performing } \\
\text { work }\end{array}$} & Between groups & 49.9730 & 12 & 4.16 & *8.7869 \\
\hline & Within groups & 230.8057 & 487 & 0.47 & \\
\hline & Total & 280.7787 & 499 & & \\
\hline \multirow{3}{*}{$\begin{array}{l}\text { 5. Sanitation, ventilation and furnishing facilities in the } \\
\text { company are good }\end{array}$} & Between groups & 75.6465 & 12 & 6.30 & ${ }^{*} 14.9399$ \\
\hline & Within groups & 205.4895 & 487 & 0.42 & \\
\hline & Total & 281.1360 & 499 & & \\
\hline \multirow[t]{3}{*}{ 6. Canteen and refreshment facilities arrangement are good } & Between groups & 76.0390 & 12 & 6.34 & ${ }^{*} 12.3835$ \\
\hline & Within groups & 249.1962 & 487 & 0.51 & \\
\hline & Total & 325.2352 & 499 & & \\
\hline \multirow[t]{3}{*}{ 7. Safety standards maintained by the department are good } & Between groups & 68.5980 & 12 & 5.72 & ${ }^{*} 14.4901$ \\
\hline & Within groups & 192.1274 & 487 & 0.39 & \\
\hline & Total & 260.7254 & 499 & & \\
\hline \multicolumn{6}{|l|}{ (F) Employee Friendly Work Environment } \\
\hline \multirow{3}{*}{$\begin{array}{l}\text { 1. The top management believes that human sources are } \\
\text { an extremely important resource and that they have to be } \\
\text { treated more humanly. }\end{array}$} & Between groups & 87.6055 & 12 & 7.30 & ${ }^{*} 14.8151$ \\
\hline & Within groups & 239.9798 & 487 & 0.49 & \\
\hline & Total & 327.5853 & 499 & & \\
\hline \multirow{3}{*}{$\begin{array}{l}\text { 2. The top management of this organisation goes out of its } \\
\text { way to make sure that employees enjoy their work }\end{array}$} & Between groups & 70.1735 & 12 & 5.85 & ${ }^{*} 11.4846$ \\
\hline & Within groups & 247.9731 & 487 & 0.51 & \\
\hline & Total & 318.1466 & 499 & & \\
\hline 3. The top management is willing to invest a considerable & Between groups & 89.5615 & 12 & 7.46 & ${ }^{*} 14.8235$ \\
\hline
\end{tabular}




\begin{tabular}{|c|c|c|c|c|c|}
\hline Particulars & ANOVA & Sum of Squares & $\mathrm{df}$ & Mean Squares & $F$ \\
\hline \multirow{2}{*}{$\begin{array}{l}\text { part of their time and other resource to ensure the } \\
\text { development of employees. }\end{array}$} & Within groups & 245.1990 & 487 & 0.50 & \\
\hline & Total & 334.7605 & 499 & & \\
\hline \multirow{3}{*}{$\begin{array}{l}\text { 4. The top management of this organisation makes efforts } \\
\text { to identify and utilize the potential of employees. }\end{array}$} & Between groups & 75.1835 & 12 & 6.27 & ${ }^{*} 13.2674$ \\
\hline & Within groups & 229.9779 & 487 & 0.47 & \\
\hline & Total & 305.1614 & 499 & & \\
\hline \multirow{3}{*}{$\begin{array}{l}\text { 5. Seniors guide their juniors and prepare them for future } \\
\text { responsibilities / roles they are likely to take-up }\end{array}$} & Between groups & 59.5505 & 12 & 4.96 & *8.8963 \\
\hline & Within groups & 271.6581 & 487 & 0.56 & \\
\hline & Total & 331.2086 & 499 & & \\
\hline \multirow{3}{*}{$\begin{array}{l}\text { 6. When seniors delegate authority to juniors, the juniors } \\
\text { use it as an opportunity for development }\end{array}$} & Between groups & 58.6265 & 12 & 4.89 & *8.6682 \\
\hline & Within groups & 274.4798 & 487 & 0.56 & \\
\hline & Total & 333.1063 & 499 & & \\
\hline \multirow{3}{*}{$\begin{array}{l}\text { 7. Employees are not afraid to express or discuss their } \\
\text { feeling with their colleagues. }\end{array}$} & Between groups & 109.7160 & 12 & 9.14 & ${ }^{*} 17.2468$ \\
\hline & Within groups & 258.1724 & 487 & 0.53 & \\
\hline & Total & 367.8884 & 499 & & \\
\hline \multirow{3}{*}{$\begin{array}{l}\text { 8. Employees are encouraged to take initiative and do } \\
\text { things on their own without having to wait for instructions } \\
\text { from supervisors. }\end{array}$} & Between groups & 65.0325 & 12 & 5.42 & *8.2775 \\
\hline & Within groups & 318.8448 & 487 & 0.65 & \\
\hline & Total & 383.8773 & 499 & & \\
\hline \multirow{3}{*}{$\begin{array}{l}\text { 9. Employees are not afraid to express or discuss their } \\
\text { feelings with their superiors. }\end{array}$} & Between groups & 87.9220 & 12 & 7.33 & ${ }^{*} 16.5863$ \\
\hline & Within groups & 215.1274 & 487 & 0.44 & \\
\hline & Total & 303.0494 & 499 & & \\
\hline \multirow{3}{*}{$\begin{array}{l}\text { 10. Employees are not afraid to express or discuss their } \\
\text { feelings with their subordinates. }\end{array}$} & Between groups & 83.2965 & 12 & 6.94 & ${ }^{*} 16.3402$ \\
\hline & Within groups & 206.8798 & 487 & 0.42 & \\
\hline & Total & 290.1763 & 499 & & \\
\hline \multirow{3}{*}{$\begin{array}{l}\text { 11. Employees are encouraged to experiment with new } \\
\text { methods and try out creative ideas. }\end{array}$} & Between groups & 125.2725 & 12 & 10.44 & ${ }^{*} 22.4939$ \\
\hline & Within groups & 226.0162 & 487 & 0.46 & \\
\hline & Total & 351.2887 & 499 & & \\
\hline \multirow{3}{*}{$\begin{array}{l}\text { 12. Weakness of employees is communicated to them in a } \\
\text { non-threatening way. }\end{array}$} & Between groups & 80.3895 & 12 & 6.70 & ${ }^{*} 13.3509$ \\
\hline & Within groups & 244.3629 & 487 & 0.50 & \\
\hline & Total & 324.7524 & 499 & & \\
\hline \multirow{3}{*}{$\begin{array}{l}\text { 13. Employees in this organisation are very informal and } \\
\text { do not hesitate to discuss their personal problems with their } \\
\text { superiors/ subordinates. }\end{array}$} & Between groups & 75.9590 & 12 & 6.33 & ${ }^{*} 10.7058$ \\
\hline & Within groups & 287.9429 & 487 & 0.59 & \\
\hline & Total & 363.9019 & 499 & & \\
\hline \multirow{3}{*}{$\begin{array}{l}\text { 14. Communication in the organisation is both at upwards } \\
\text { and downward is effective. }\end{array}$} & Between groups & 83.5830 & 12 & 6.97 & ${ }^{*} 15.4322$ \\
\hline & Within groups & 219.8057 & 487 & 0.45 & \\
\hline & Total & 303.3887 & 499 & & \\
\hline \multirow{3}{*}{$\begin{array}{l}\text { 15. People in this organisation don't have any fixed mental } \\
\text { impression about each other. }\end{array}$} & Between groups & 59.6320 & 12 & 4.97 & *9.1066 \\
\hline & Within groups & 265.7495 & 487 & 0.55 & \\
\hline & Total & 325.3815 & 499 & & \\
\hline \multirow[t]{2}{*}{ 16. Team spirit is of high order in this organisation. } & Between groups & 64.5290 & 12 & 5.38 & ${ }^{*} 10.2916$ \\
\hline & Within groups & 254.4590 & 487 & 0.52 & \\
\hline
\end{tabular}




\begin{tabular}{|c|c|c|c|c|c|}
\hline Particulars & ANOVA & Sum of Squares & $\mathrm{df}$ & Mean Squares & F \\
\hline & Total & 318.9880 & 499 & & \\
\hline \multicolumn{6}{|l|}{ (G) Development Oriented Performance Appraisal } \\
\hline \multirow{3}{*}{$\begin{array}{l}\text { 1. Our performance appraisal system provides feedback } \\
\text { from superiors. }\end{array}$} & Between groups & 67.6735 & 12 & 5.64 & ${ }^{*} 12.8039$ \\
\hline & Within groups & 214.4981 & 487 & 0.44 & \\
\hline & Total & 282.1716 & 499 & & \\
\hline \multirow{3}{*}{$\begin{array}{l}\text { 2. There is high employee participation in the appraisal } \\
\text { process. }\end{array}$} & Between groups & 66.5395 & 12 & 5.54 & ${ }^{*} 12.6220$ \\
\hline & Within groups & 213.9429 & 487 & 0.44 & \\
\hline & Total & 280.4824 & 499 & & \\
\hline \multicolumn{6}{|l|}{ 3. Performance appraisal is based on } \\
\hline \multirow[t]{3}{*}{ (a) Individual results } & Between groups & 73.0000 & 12 & 6.08 & ${ }^{*} 12.0577$ \\
\hline & Within groups & 245.7007 & 487 & 0.50 & \\
\hline & Total & 318.7007 & 499 & & \\
\hline \multirow[t]{3}{*}{ (b) Group results } & Between groups & 57.8340 & 12 & 4.82 & ${ }^{*} 12.9009$ \\
\hline & Within groups & 181.9324 & 487 & 0.37 & \\
\hline & Total & 239.7664 & 499 & & \\
\hline \multirow{3}{*}{$\begin{array}{l}\text { (c) Quantifiable standards, such as the value of project } \\
\text { completed. }\end{array}$} & Between groups & 55.2235 & 12 & 4.60 & *9.5256 \\
\hline & Within groups & 235.2781 & 487 & 0.48 & \\
\hline & Total & 290.5016 & 499 & & \\
\hline \multirow[t]{3}{*}{ (d) Qualitative standards, such as teamwork. } & Between groups & 80.6495 & 12 & 6.72 & ${ }^{*} 15.9880$ \\
\hline & Within groups & 204.7179 & 487 & 0.42 & \\
\hline & Total & 285.3674 & 499 & & \\
\hline \multirow{3}{*}{$\begin{array}{l}\text { 4. The objective of the appraisal process is employee's } \\
\text { development. }\end{array}$} & Between groups & 49.0990 & 12 & 4.09 & *8.4092 \\
\hline & Within groups & 236.9540 & 487 & 0.49 & \\
\hline & Total & 286.0530 & 499 & & \\
\hline \multirow{3}{*}{$\begin{array}{l}\text { 5. If performance problems occur they are discussed with } \\
\text { the appropriate individuals or groups. }\end{array}$} & Between groups & 60.7560 & 12 & 5.06 & ${ }^{*} 12.3081$ \\
\hline & Within groups & 200.3295 & 487 & 0.41 & \\
\hline & Total & 261.0855 & 499 & & \\
\hline \multirow{3}{*}{$\begin{array}{l}\text { 6. Performance appraisal reports in our organisation are } \\
\text { based on objective assessment and adequate information } \\
\text { and not on favoritism. }\end{array}$} & Between groups & 60.6645 & 12 & 5.06 & ${ }^{*} 12.4831$ \\
\hline & Within groups & 197.2248 & 487 & 0.40 & \\
\hline & Total & 257.8893 & 499 & & \\
\hline \multicolumn{6}{|l|}{ (H) Compensation } \\
\hline \multirow{3}{*}{$\begin{array}{l}\text { 1. Each individual's compensation package is determined } \\
\text { through a document procedure that is consistent with } \\
\text { organisation's compensation policy, strategy and plan. }\end{array}$} & Between groups & 58.5695 & 12 & 4.88 & *9.8989 \\
\hline & Within groups & 240.1229 & 487 & 0.49 & \\
\hline & Total & 298.6924 & 499 & & \\
\hline \multirow{3}{*}{$\begin{array}{l}\text { 2. Compensation is primarily determined by results } \\
\text { achieved / contribution to the company. }\end{array}$} & Between groups & 38.5930 & 12 & 3.22 & ${ }^{*} 7.0405$ \\
\hline & Within groups & 222.4600 & 487 & 0.46 & \\
\hline & Total & 261.0530 & 499 & & \\
\hline \multirow{2}{*}{$\begin{array}{l}\text { 3. Decisions regarding an individual's compensation } \\
\text { package are communicated to the individual. }\end{array}$} & Between groups & 36.9065 & 12 & 3.08 & *6.1268 \\
\hline & Within groups & 244.4645 & 487 & 0.50 & \\
\hline
\end{tabular}




\begin{tabular}{|c|c|c|c|c|c|}
\hline Particulars & ANOVA & Sum of Squares & $\mathrm{df}$ & Mean Squares & F \\
\hline & Total & 281.3710 & 499 & & \\
\hline \multirow{3}{*}{$\begin{array}{l}\text { 4. In our company high performers are given higher pay } \\
\text { package. }\end{array}$} & Between groups & 64.8205 & 12 & 5.40 & ${ }^{*} 13.9640$ \\
\hline & Within groups & 188.3864 & 487 & 0.39 & \\
\hline & Total & 253.2069 & 499 & & \\
\hline \multicolumn{6}{|l|}{ (I) Career Development } \\
\hline \multirow{3}{*}{$\begin{array}{l}\text { 1. In our company a personal development plan is created } \\
\text { and maintained for each individual. }\end{array}$} & Between groups & 68.0800 & 12 & 5.67 & $* 9.8780$ \\
\hline & Within groups & 279.7050 & 487 & 0.57 & \\
\hline & Total & 347.7850 & 499 & & \\
\hline \multirow{3}{*}{$\begin{array}{l}\text { 2. Company provides every employee with opportunities to } \\
\text { choose a career path to suit the individual's core } \\
\text { competence. }\end{array}$} & Between groups & 56.3550 & 12 & 4.70 & $*^{*} 7.9002$ \\
\hline & Within groups & 289.4967 & 487 & 0.59 & \\
\hline & Total & 345.8517 & 499 & & \\
\hline \multirow{3}{*}{$\begin{array}{l}\text { 3. An individual's development plan and activities are } \\
\text { periodically reviewed to determine whether organisational } \\
\text { competency needs will be met. }\end{array}$} & Between groups & 50.1160 & 12 & 4.18 & *7.1386 \\
\hline & Within groups & 284.9124 & 487 & 0.59 & \\
\hline & Total & 335.0284 & 499 & & \\
\hline \multirow{3}{*}{$\begin{array}{l}\text { 4. Individuals in this company have clear career paths } \\
\text { within the organisation. }\end{array}$} & Between groups & 58.3285 & 12 & 4.86 & *8.8112 \\
\hline & Within groups & 268.6531 & 487 & 0.55 & \\
\hline & Total & 326.9816 & 499 & & \\
\hline \multirow{3}{*}{$\begin{array}{l}\text { 5. Our company has created a learning environment in the } \\
\text { organisation for both professional and personal growth. }\end{array}$} & Between groups & 62.4260 & 12 & 5.20 & *9.2921 \\
\hline & Within groups & 272.6450 & 487 & 0.56 & \\
\hline & Total & 335.0710 & 499 & & \\
\hline \multirow{3}{*}{$\begin{array}{l}\text { 6. Job rotation in this organisation facilities employee } \\
\text { development. }\end{array}$} & Between groups & 68.2830 & 12 & 5.69 & *9.6003 \\
\hline & Within groups & 288.6524 & 487 & 0.59 & \\
\hline & Total & 356.9354 & 499 & & \\
\hline \multicolumn{6}{|l|}{ (J) Value-Added Incentives } \\
\hline \multirow{3}{*}{$\begin{array}{l}\text { 1. Employees are offered an extremely flexible } \\
\text { compensation and benefits package like housing assistance, } \\
\text { stock options, soft loans and asset acquisition assistance. }\end{array}$} & Between groups & 83.2505 & 12 & 6.94 & ${ }^{*} 7.4058$ \\
\hline & Within groups & 456.2074 & 487 & 0.94 & \\
\hline & Total & 539.4579 & 499 & & \\
\hline \multirow{3}{*}{$\begin{array}{l}2 . \quad \text { Extensive performance-based incentives and } \\
\text { bonuses are available to all employees. }\end{array}$} & Between groups & 70.0488 & 12 & 5.84 & *9.1501 \\
\hline & Within groups & 310.6867 & 487 & 0.64 & \\
\hline & Total & 380.7355 & 499 & & \\
\hline
\end{tabular}

Source: Primary Survey

* Significant at $1 \%$ level of significance

** Significant at $5 \%$ level of significance 